\title{
Consumer response to different advertising appeals: The role of brand value and the perceptual fit of an extended brand for high-involvement products
}

\author{
Rosa Prafitri Juniarti ${ }^{*}$, Adi Zakaria Afiff ${ }^{2}$ \\ ${ }^{1}$ Department of Management, Faculty of Economics, Universitas Negeri Surabaya, \\ Surabaya, Indonesia \\ ${ }^{2}$ Department of Management, Faculty of Economics and Business, Universitas Indonesia, \\ Depok, Indonesia \\ *Corresponding Author(s) Email: rosajuniarti@unesa.ac.id
}

\section{ABSTRACT}

Brand extension is a topic that has been widely discussed by academics and practitioners in various studies. Unfortunately, there are only a few that address the role of product involvement, advertising appeals, and value dimensions in the extension acceptance as their main issue. Therefore, this study aims to mixed three controlling factors which are product involvement, advertising appeals, and brand value dimensions in determining how consumers respond to the parent brand and extended brand. This study was designed to test the possible interaction in a $2 \times 2 \times 2$ full-factorial between advertising appeals (informational vs. emotional), brand extension perceived fit (high vs. low), and value dimension (symbolic vs. functional) for high involvement products. This study confirmed that there were significant differences in the main effects for both consumers' evaluation toward brand extension and the parent brand in the case of a symbolic brand and the high fit of extensions. Emotional appeals play important role in enhancing this degree because of the high level of its brand associations. As symbolic brand often referred as premium brand, the more positive the level of quality perception, the higher level of consumers' evaluation toward brand and brand loyalty will be. Thus, the more loyal consumer to the parent brand, the more positive evaluations of the extension will be.

Keywords: Advertising Appeals; Symbolic; Functional; Perceived Fit; Parent Brand; Brand Extension; High-Involvement Product
JEL Code:

M31, M37

DOI:

10.31106/jema.v17i2.6683

Article History:

Received 2020/04/14

Reviewed 2020/06/03

Revised 2020/06/27

Accepted 2020/11/12

Licensed:

CC-BY 
Consumer response to different advertising appeals: The role of brand value and the perceptual fit of an extended brand for high-involvement products by Rosa Prafitri Juniarti, Adi Zakaria Afiff

\section{Introduction}

A famous brand name often influences consumers' purchasing decisions. Brand extension is a topic that has been widely discussed by academics and practitioners in various studies. They examined the factors that influence the success of a brand extension, the types of brand extension that fit the parent brand (O'Reilly et al., 2017; Sharma \& Paudel, 2018; Hadi \& Sandhu, 2020), the quality of the parent brand (Aaker \& Keller, 1990; Völckner \& Sattler, 2006; Carter \& Curry, 2013; Verhellen et al., 2016), the cultural differences in evaluating brand extension (Henseler et al., 2010; Kim \& Park, 2019), the transfer of assets from the parent brand to the brand extension (Bhat \& Reddy, 2001; Joshi \& Yadav, 2018), attitudes towards brand extension and self-constructiveness (Boisvert \& Ashill, 2018; Dedeoğlu, 2018; Yuan et al., 2016).

Advertisements can improve consumer ratings of new products, including new products from established brands. Several researchers have proven that advertisements can increase acceptance of extensions (Dens \& De Pelsmacker, 2010b). Extensions can enhance the essential characteristics of brand associations which can help consumers understand the features and benefits of brand extensions and fit. Consumers will judge the appropriateness and consistency when the ad describes how the parent brand's attributes enhance the extension's ability to deliver (Völckner \& Sattler, 2006).

While many studies of brand extension exist in the world, only a few that address the role of product involvement, advertising appeals, and value dimensions in the extension acceptance as their main issue. Discussions about those issues need to be carried out because consumers evaluate brands in different ways. They evaluate product categories with different engagement. Likewise, the evaluation of brand extension, at high and low-level engagement, will also be different. The degree to which consumers engage with product categories influences how they evaluate extensions (Dens \& De Pelsmacker, 2010a) and advertisements (Kim et al., 2009). This shows the need to study brand extension for high-involvement products.

Furthermore, all brands have value dimensions, i.e. overall abstraction meaning that gives an identity to a brand. Brand value dimensions place a product in consumers' minds and differentiate it in the same category. Brand value dimensions can be a symbolic brand or functional brand which fulfills consumers' symbolic and functional needs. Functional brands meet immediate and practical needs and emphasize product performance against consumer functional or functional needs. Symbolic brands fulfill symbolic needs such as self- 
expression and prestige. Symbolic brands underline the social and hedonic aspects of products and features to embody the self-concept or self-image expression of consumers (Gierl \& Huettl, 2010).

Brand concept consistency on the extension product is assessed by the readiness of the brand extension to hold a particular brand concept. It depends on consumer perception whether brand-concept associations (such as status, reliability) have relevant and/ or desired relationships with a certain product (Kwon et al., 2016; Mimouni Chaabane \& Pez, 2017; Bairrada et al., 2018; Zhu et al., 2019). A brand with a more abstract concept is more elastic and can be extended to a lot of categories. On the other hand, brands with functional attributes are less elastic and will be more successful if the brand extension is more in line with the function of the brand (Albrecht et al., 2013). However, as we mentioned above there is little research that uses the concept of the brand value dimension in evaluating the parent and extended brand's attitude (Monga \& John, 2010). Therefore, this study aims to mixed three controlling factors which are product involvement, advertising appeals, and brand value dimensions in determining how consumers respond to the parent brand and extended brand.

\section{Literature Review}

\section{Perceived Parent Brands Quality}

Rajagopal (2020) and Sharma \& Paudel (2018) defined perceived brand quality as the perception or initial identification of the overall quality or superiority of a brand. Perception of quality is one of the crucial factors which can drive product success and enhances business performance (Yang, 2012; Alavinasab et al., 2017). Kim et al. (2014) stated that the role of brand quality becomes more important when companies tend to extend their product diversity. The use of original brand names (which is also known as parent brand) for product extensions proved to influence the consumers' evaluation of extended brand (Kwun \& Oh, 2007). The more positive consumer evaluation toward parent brand quality, the higher the acceptance of extended brand will be (O'Reilly et al., 2017; Hadi \& Sandhu, 2020).

\section{Brand Extension Evaluation and Perceptual Fit}

Brand extensions can be defined as the used of established brand names to introduce new product categories (Yuan et al., 2016; Dedeoğlu, 2018). Boisvert \& Ashill (2018) added that brand extension is categorized in two dimensions which are a horizontal and vertical extension. While horizontal extension means using the parent brand name to introduce new products or services in different categories. Vertical extension refers to launch a new product 
Consumer response to different advertising appeals: The role of brand value and the perceptual fit of an extended brand for high-involvement products by Rosa Prafitri Juniarti, Adi Zakaria Afiff

or service in the same category but at a cheaper price and lower quality compared to the parent brand. The relationship of the parent brand and its extension has been studied by numerous researchers. Thus, previous studies, in general, indicate that the perceptual of extension "fit" with parent brand has a positive effect on the evaluation of extended brands (Carter \& Curry, 2013; Verhellen et al., 2016). It means that the higher the level of fitness between the parent brand and the extension, the more positive consumers' evaluation (attitude) toward brand extension will be.

The perceptual fit itself can be defined as any association regarding parent brands, including categories, brand concepts, or brand-specific associations, which can connect with parent brands with brand extensions and form the basis of perceived fit. Bottomley \& Holden (2001) emphasized that there are several factors in shaping consumer evaluations of brand extensions which are the quality of the parent brand, the fit between the parent brand and the extension category, and the interaction between the two. Aaker \& Keller (1990) added that the degree of extension evaluation is due to the perception of the level of ease of use, situational involvement (Barone, 2005), the dominance of the parent brand category (Carter \& Curry, 2013), and competitor characteristics (Milberg \& Sinn, 2008).

\section{Symbolic and Functional Value Dimension}

Symbolic concepts generally used by consumers to fulfill their symbolic needs by expressing their value preferred (self-expression), social status image, ego-identification (self-enhancement) such as dominance, prestige, and uniqueness (Kwon et al., 2016; Chaabane \& Pez, 2017). Symbolic needs itself are defined by Salehzadeh et al. (2018) as the desire for products that meet internal needs for self-enhancement, role position, group membership, or identification of the ego. The use of symbolic terms refers to the image that was formed by marketers in brand management.

Whereas the functional of brand value refers to the perception of consumers of how well the brand will satisfy their utilitarian needs, such as the quality of the products, product performances, and the level of risk (Albrecht et al., 2013). In a simple meaning, a functional brand is the perception of usefulness and competence of a brand/product that was designed by marketers to fulfill consumption needs. Previous studies from Albrecht et al. (2013) show that there is a positive and significant relationship between functional value and consumers' evaluation toward extensions. Functional values were more heavily affect the level for both luxury and non-luxury brand extensions compared to the hedonic value. 


\section{Advertising Appeals}

The effect of advertising appeals on consumer response was varied for each individual because of the different conditions of informational load, the perception of the level of involvement, age, and market pressure (Rhee \& Jung, 2019). Advertising appeals itself can be defined as the general tone and message strategies that marketers generally used to grab attention and to attract consumer willingness to buy (Teichert et al., 2018).

Advertising execution strategies can be roughly divided into two dimensional which is informational and transformational/emotional appeals. In a simple meaning, informational advertising informs consumers clearly and logically by providing factual and relevant data ("the reason why") about the brand benefit (Pashna et al., 2019) Belch \& Belch (2013) added that informational advertising tends to be informative and advertisers generally use it to try to convince consumers that their products or services have certain attributes or provide certain benefits that meet consumer needs. Prajogo \& Purwanto (2020) stated that due to the benefit that consumers obtain after exposed by informative advertising, they tend to create a buzz voluntarily. The more information that is given by new product extension advertising campaign, the further away the positioning of the extended brand from the parent brand will be as perceived fit between the parent brand and extensions will decrease and it will impact on the influence of attitude toward the parent brand on brand-extension evaluation (Nan, 2006).

Emotional appeals are aimed to evoke consumer feelings and emotions (Dens \& De Pelsmacker, 2010b). Positive emotional advertising provides strong brand signals and stimulates category-based processing. Also, the absence of specific information from extensions in advertisements will cause the audience to only use existing cues such as brand names, perceived parent brand quality, and perceived fit to evaluate extensions (Klink \& Smith, 2001; Primanto \& Dharmmesta, 2019).

\section{Hypotheses Development}

A symbolic brand that shares prestige orientation and brand image to its brand extension shows the achievement of brand extension fit (Bhat \& Reddy, 2001). In this context, prestige orientation and brand relate to parent brands and brand extensions (Lye et al., 2001). The image fit influences consumers to believe that they can enjoy similar advantages from parent brands and brand extensions (Eren-Erdogmuş \& Büdeyri-Turan, 2012; Ferguson et al., 2016; Eren-Erdogmus et al., 2018). Hereafter, fit perception can be created even though the brand extension is very different from the product category of the parent brand. 
Consumer response to different advertising appeals: The role of brand value and the perceptual fit of an extended brand for high-involvement products by Rosa Prafitri Juniarti, Adi Zakaria Afiff

On the other hand, the brand extension ad will enhance the brand image because it can communicate the established extension, increase positive brand association, and strengthen brand image (Völckner \& Sattler, 2006). Advertising execution strategy can be divided into informational and emotional advertisements (Pashna et al., 2019; Rhee \& Jung, 2019). The positive emotional advertisement gives a strong brand signal and stimulates category-based processing. Moreover, the absence of specific information of extension in the advertisement causes audiences to use the existing cues, such as brand name, perceived parent brand quality and perceived fit to evaluate extension (Klink \& Smith, 2001; Kwun \& Oh, 2007; O'Reilly et al., 2017; Hadi \& Sandhu, 2020). The more audiences love an ad, the more they like the advertised product. Meanwhile, the more information is given in the new extension communication, the more new characteristics from extension become prominent, and brand extension positioning is further from the parent brand (Nan, 2006). An increase in the amount of product information reduces the effect of generic brand names and fit in particular, because information provides several reasons for the evaluation of products without the brand name itself (Dens \& De Pelsmacker, 2010a).

Furthermore, consumers receive a brand fit better when the parent brand and brand extension have the same brand concept. Companies can implement many communication strategies to increase perceived fit and ultimately increase brand acceptance among consumers. The low-fit perception can be overcome with an effective communication strategy that focuses on relationship associations that provide a clear relationship between the parent brand and brand extension (Shokri \& Alavi, 2019; Zhang et al., 2020). A high fit will indicate a positive evaluation of the parent brand (Arikan et al., 2016; Childs \& Jin, 2020). A successful brand extension will bring high confidence in the brand extension which is then transferred back to the parent brand (Joshi \& Yadav, 2018).

The feedback effect on brand extensions can differ due to the type of advertisement. If the introduction of brand extensions uses informational advertising, the new information will form new brand extension associations and influence associations to the parent brand. If a brand extension introduction implements emotional advertising, new information about the brand extension product will be limited. Consumers will judge advertisements based on important signals that link the parent brand to the brand extension. In this case, attitudes towards brand extension have less influence on attitudes towards the parent brand because the ad shows attributes of the parent brand without meaningful information about the brand extension (Nan, 2006; Dens \& De Pelsmacker, 2010b). 
$\mathrm{H}_{1}$ : Attitude toward brand extension and parent brand is higher for emotional than informational appeal in case of a symbolic brand and the high fit of extensions.

$\mathrm{H}_{2}$ : Consumers' evaluation of brand extension and parent brand will be more favorable for emotional than informational appeal when it is a symbolic brand and the low fit of extensions.

$\mathrm{H}_{3}$ : Attitude toward brand extension and parent brand is higher for informational than emotional appeal in case of a functional brand and the high fit of extensions.

$\mathrm{H}_{4}$ : There is no difference in the level of attitude toward brand extension and parent brand for both emotional and informational appeal in case of a functional brand and the low fit of extensions.

$\mathrm{H}_{5}$ : Consumers' evaluations on brand extension and parent brand is higher for symbolic than functional concept under emotional appeals and the high fit of extension.

$\mathrm{H}_{6}$ : Consumers' evaluations on brand extension and parent brand is higher for functional than symbolic concept under informational appeals and the high fit of extension.

\section{Methods}

This study was designed to test the possible interaction between advertising appeals (informational, emotional), brand extension perceived fit (high, low), and value dimension (symbolic, functional) for a high involvement product category. Therefore, a 2 × 2 × 2 fullfactorial between-subject design was set up to examined the proposed hypotheses. Real mobile phone brands namely Apple (iPhone) and Nexian were used in this study to enhance ecological validity (Lau \& Phau, 2007). Camera and television were chosen as extension product focus in this study because of the strong beliefs that generally consumer has about its attribute (Flores et al., 2014). This study used printed advertisements as an experimental stimulus. There are eight combinations of stimuli based on the experimental design (Table 1). The detailed printed ad stimulus can be viewed in Appendix 1a-h.

Table 1. Experiment Design

\begin{tabular}{lcccc}
\cline { 2 - 5 } & \multicolumn{2}{c}{ Symbolic } & \multicolumn{2}{c}{ Functional } \\
\cline { 2 - 5 } & High Fit & Low Fit & High Fit & Low Fit \\
\hline Emotional Advertising & $\mu 1$ & $\mu 2$ & $\mu 3$ & $\mu 4$ \\
Informational Advertising & $\mu 5$ & $\mu 6$ & $\mu 7$ & $\mu 8$ \\
\hline
\end{tabular}

Three pretests were employed to determine brands that were symbolic or functional in nature, to identify advertisement stimuli and brands extension perceived fit whether it's 
Consumer response to different advertising appeals: The role of brand value and the perceptual fit of an extended brand for high-involvement products by Rosa Prafitri Juniarti, Adi Zakaria Afiff

informational or emotional and high or low. Through an online survey, 228 undergraduate students at the Faculty of Economics and Business, Universitas Indonesia, were randomly participated in the experiment and divided across various treatments.

Table 2. Independent t-Test Results Between Symbolic and Functional

\begin{tabular}{lcc}
\hline Brand & Symbolic $(\boldsymbol{\mu})$ & Functional $(\boldsymbol{\mu})$ \\
\hline Apple & 6.829 & 5.717 \\
Nexian & 3.162 & 4.063 \\
\hline
\end{tabular}

A first pretest was run to identify these brands whether it can be classified as symbolic or functional. A questionnaire with semantic differential scales that consists of several items was distributed to 228 target respondents. Thus, the mean ratings of items symbolic and functional were compared using an independent sample t-test. Table 2 shows that Apple demonstrated much stronger association ratings than their functional feature with image related attributes such as prestige, status, and elegance. While Nexian tends to be more functional focused (easy to use, lower prices, and multi-features). In addition, the result of the independent $\mathrm{t}$-test shown in Table 2 also shows that Apple's brand is more superior compared to Nexian.

Table 3. Anova Test Results of Perceived Fit and Brand

\begin{tabular}{lcc}
\hline \multirow{2}{*}{ Product Category } & \multicolumn{2}{c}{ Perceived Fit $(\boldsymbol{\mu})$} \\
\cline { 2 - 3 } & Camera & Television \\
\hline Apple & 4.750 & 4.885 \\
Nexian & 4.296 & 4.702 \\
\hline
\end{tabular}

A second pretest was run to ensure that the stimuli extensions were a reasonable fit for parent brands. The extension of the high involvement product category chosen for Apple and Nexian was camera and television. The result of brand extension perceived fit compared means indicated that there are no differences in brand extension mean scores to those of respective parent brands. It means that both the selected extensions indicated a reasonably good fit with the parent brands. Table 3 shows that the respondent of this study slightly perceived that television for both brands has a higher extension fit with the parent brands than the camera.

Finally, a third pretest was conducted to determine advertisement stimuli strategy whether it's informational or emotional. There is no difference in symbolic and functional 
dimension mean scores of each advertisement stimuli both informational and emotional stimuli.

Table 4. Questionnaire Items

\begin{tabular}{|c|c|c|c|}
\hline Variable & Code & Item & Reference \\
\hline \multirow{3}{*}{$\begin{array}{l}\text { Attitude } \\
\text { Toward } \\
\text { Extended } \\
\text { Brand (AEX) }\end{array}$} & AEX1 & $\begin{array}{l}\text { According to me, the extended brand (Apple } \\
\text { TV/Apple Camera/Nexian TV/Nexian Camera) } \\
\text { that's being advertised is great. }\end{array}$ & \\
\hline & AEX2 & $\begin{array}{l}\text { My attitude toward the extended brand (Apple } \\
\text { TV/Apple Camera/Nexian TV/Nexian Camera) } \\
\text { that's being advertised is very positive. }\end{array}$ & \\
\hline & AEX3 & $\begin{array}{l}\text { I like the extended brand (Apple TV/Apple } \\
\text { Camera/Nexian TV/Nexian Camera) that's } \\
\text { being advertised. }\end{array}$ & $\begin{array}{l}\text { Dwivedi et al., } \\
\text { (2010) }\end{array}$ \\
\hline \multirow{3}{*}{$\begin{array}{l}\text { Attitude } \\
\text { Toward } \\
\text { Parent Brand } \\
\text { (APB) }\end{array}$} & APB1 & $\begin{array}{l}\text { According to me, the parent brand } \\
\text { (Apple/Nexian) that's being advertised is great. }\end{array}$ & \\
\hline & APB2 & $\begin{array}{l}\text { My attitude toward the parent brand } \\
\text { (Apple/Nexian) that's being advertised is very } \\
\text { positive. }\end{array}$ & \\
\hline & APB3 & $\begin{array}{l}\text { I like the parent brand (Apple/Nexian) that's } \\
\text { being advertised. }\end{array}$ & \\
\hline
\end{tabular}

In order to test the proposed hypotheses $\left(\mathrm{H}_{1}-\mathrm{H}_{6}\right)$, validity and reliability measurements of consumers' evaluation (attitude) toward brand extension (AEX) and their attitude toward parent brands (APB) were carried out for the basis of independent sample t-test analysis. The results of the validity and reliability testing in Table 4 show that all instruments used in this study were valid and reliable.

Table 5. Validity and Reliability Result

\begin{tabular}{lccccc}
\hline Variable/Item & $\begin{array}{c}\text { Pearson } \\
\text { Correlation }\end{array}$ & Criteria & $\begin{array}{c}\text { Cronbach's } \\
\text { Alpha }\end{array}$ & Criteria & Decision \\
\hline AEX & & & 0.903 & $>0.600$ & Reliable \\
AEX1 & 0.912 & $>0.130$ & & & Valid \\
AEX2 & 0.903 & $>0.130$ & & & Valid \\
AEX3 & 0.881 & $>0.130$ & & & Valid \\
APB & & & 0.953 & & Reliable \\
APB1 & 0.937 & $>0.130$ & & & Valid \\
APB2 & 0.955 & $>0.130$ & & Valid \\
APB3 & 0.942 & $>0.130$ & & Valid \\
\hline
\end{tabular}


Consumer response to different advertising appeals: The role of brand value and the perceptual fit of an extended brand for high-involvement products by Rosa Prafitri Juniarti, Adi Zakaria Afiff

\section{Result and Discussion}

Table 6. Independent sample t-test result

\begin{tabular}{lllllll}
\hline \multirow{2}{*}{ Hypotheses } & \multicolumn{4}{c}{ AEXT } & APB & Decision \\
\cline { 2 - 6 } & Sig & Mean Comparison & Sig & Mean Comparison & \\
\hline $\mathrm{H}_{1}$ & $\mu 1>\mu 5$ & .000 & $\mu 1(5.006)>\mu 5(3.809)$ & .000 & $\mu 1(5.810)>\mu 5(3.611)$ & Accepted \\
$\mathrm{H}_{2}$ & $\mu 2>\mu 6$ & .002 & $\mu 2(5.932)>\mu 6(5.025)$ & .000 & $\mu 2(6.488)>\mu 6(4.580)$ & Accepted \\
$\mathrm{H}_{3}$ & $\mu 7>\mu 3$ & .038 & $\mu 7(4.803)<\mu 3(5.401)$ & .000 & $\mu 7(4.137)<\mu 3(5.963)$ & Rejected \\
$\mathrm{H}_{4}$ & $\mu 4=\mu 8$ & .954 & $\mu 4(5.655)>\mu 8(5.638)$ & .000 & $\mu 4(6.517)>\mu 8(4.787)$ & Rejected \\
$\mathrm{H}_{5}$ & $\mu 1>\mu 3$ & .188 & $\mu 1(5.006)<\mu 3(5.401)$ & .613 & $\mu 1(5.810)<\mu 3(5.963)$ & Rejected \\
$\mathrm{H}_{6}$ & $\mu 7>\mu 5$ & .001 & $\mu 7(4.803)>\mu 5(3.809)$ & .050 & $\mu 7(4.137)>\mu 5(3.611)$ & Accepted \\
\hline
\end{tabular}

An independent sample t-test analysis for the 2 (informational vs. emotional advertising appeals) x 2 (high vs. low perceived fit between the parent brand and extensions) x 2 (symbolic vs. functional brand value) was conducted to test the hypotheses of the study. In general, there are only 2 of 6 hypotheses statement that can be accepted and has similar findings to the previous studies. This study was able to confirm $\mathrm{H}_{1}$ and $\mathrm{H}_{2}$, as there were significant differences in the main effects for both consumers' evaluation toward brand extension and the parent brand. For the case of the symbolic brand and the high fit of extensions, consumers evaluate brand extensions and parent brand for emotional appeals is higher rather than informational appeal (AEX; $\mu 1$ (5.006) > $\mu 5$ (3.809), $p<0.050$ and APB; $\mu 1(5.810)>\mu 5$ (3.611), $p<0.050)$. While for the case of a symbolic brand and the low fit of extensions, consumers evaluation of brand extensions and parent brand is higher for emotional rather than informational appeal (AEX; $\mu 2$ (5.932) $>\mu 6(5.025), p<0.050$ and APB; $\mu 2(6.488)>\mu 6(4.580), p<0.050)$. This highlights that the combination of symbolic brand value and emotional appeals play important role in enhancing the degree of attitude toward brand extension and parent brand in the level of perceptual fit between parent and extended brand. Audrin et al., (2017) stated that luxury brands that provide strong symbolic benefits to consumers may enhance the perception of quality, especially for materialist consumers. Eren-Erdogmuş \& Büdeyri-Turan (2012) and Esmaeilpour (2015) added that there is a significant relationship between symbolic (personality congruence) and brand prestige and perceived quality. As prestige brand quality assumes quality, the more positive the level of quality perception, the higher level of consumers' evaluation toward brand and brand loyalty will be. Thus, the more loyal consumer to the parent brand, the more positive evaluations of the extension will be (Liu et al., 2017). On the other hand, Völckner \& Sattler 
(2006) and Figueiredo \& Eiriz (2020) add a new perspective by argues that the emotional use of prestige (symbolic) products is much more important than their functionality usage. Emotional advertisement is more acceptable to introduce a symbolic brand because of the high level of its brand associations.

The result of this study failed to prove the proposed hypotheses 3 which stated that attitude toward brand extension and parent brand is considerably higher for informational than emotional appeal in case of a functional brand and the high fit of extensions. Table 5 shows that the degree of attitude toward parent brand and extension for the high fit product was higher when marketers use emotional appeals as an advertisement execution strategy especially in functional conditions (AEX; $\mu 7$ (4.803) $<\mu 3$ (5.401), $p<0.050$ and APB; $\mu 7$ $(4.137)<\mu 3(5.963), p<0.050) . \mathrm{H}_{3}$ of this study was rejected as an unexpectedly emotional ad execution strategy has a significant contribution in defining the level of consumers' evaluation. Matthes (2013) suggest that emotional appeals play a key role in shaping consumers' brand attitude. Emotional appeals are considered as the most effective strategy than informational appeals when the purpose of the advertising act was to persuade (Teichert et al., 2018), to increase the level of information processing, to grab attention, and brand recall (Dens \& De Pelsmacker, 2010b). Whereas the proposed hypotheses of this study which stated that in the case of functionality brand, there is no significant difference of attitude toward brand extension and parent brand for the low fit product in the different advertisement appeals $\left(\mathrm{H}_{4}\right)$ was rejected due to their insignificancy $p$-value $(\mathrm{AEX} ; \mu 4(5.655)>\mu 8(5.638)$, $p>0.050$ and APB; $\mu 4(6.517)>\mu 8$ (4.787), $p<0.050)$. This highlights that the low fit perceptions of brand extension for a functional brand will partially lead the degree of attitude toward parent brand and extension in each advertisement appeals groups.

The result of this study also was not able to confirm $\mathrm{H}_{5}$ which stated that the level of consumers' evaluation toward parent brand and extension will be favorable when there are the high fit perceptions of brand extension for both symbolic and functional in the case of emotional advertising (AEX; $\mu 1$ (5.006) < $\mu 3$ (5.401), $p>0.050$ and APB; $\mu 1(5.810)<\mu 3$ (5.963), $p>0.050)$. It means that there is no difference between symbolic and functional dimension mean scores in responding to emotional advertisement stimuli when the perceptual fit between brand extension and parent brand was high. Participants in this study were tended to have the same score evaluations in regards to the design of the printed advertisement stimulus that used as the object of the experiment.

Finally, this study was confirmed $\mathrm{H}_{6}$ which stated that the level of consumers' evaluation toward parent brand and extension is higher for a functional brand in case of the high fit 
Consumer response to different advertising appeals: The role of brand value and the perceptual fit of an extended brand for high-involvement products by Rosa Prafitri Juniarti, Adi Zakaria Afiff

perceptions of brand extension in informational advertising (AEX; $\mu 7$ (4.803)> $\mu 5$ (3.809), $p$ $<0.050$ and APB; $\mu 7$ (4.137) > $\mu 5$ (3.611), $p<0.050)$. This result of the study supports the conclusion of Prajogo \& Purwanto (2020) and Lye et al., (2001) who stated that due to the reason that perceived quality influences functional brands more than prestige (symbolic) brands, marketers tend to convince consumers that their products or services have offered better functional set advantages that will meet consumer needs by maximizing the use of informational advertising. Dens \& De Pelsmacker (2010a) added that the use of camera and television as the extension was resulting in their dependence on informational appeals especially the nature of the product itself which can be classified as a high-involvement product category.

\section{Conclusion and Suggestion}

This study aims to mixed three controlling factors which is product involvement, advertising appeals, and brand value dimensions in determining how consumers respond to the parent brand and extended brand. The findings reveal that there were significant differences in the main effects for both consumers' evaluation toward brand extension and the parent brand in the case of the symbolic brand and the high fit of extensions. Emotional appeals play important role in enhancing this degree because of the high level of its brand associations. As symbolic brand often referred as premium brand, the more positive the level of quality perception, the higher level of consumers' evaluation toward brand and brand loyalty will be. Thus, the more loyal consumer to the parent brand, the more positive evaluations of the extension will be. The result of this study also proves there is no difference between symbolic and functional dimension mean scores in responding to emotional advertisement stimuli when the perceptual fit between brand extension and parent brand was high as participants in this study were tended to have the same score evaluations in regards the design of printed advertisement stimulus that used as the object of the experiment. Finally, this study was able to confirm that the level of consumers' evaluation toward parent brand and extension is higher for the functional brand in case of the high fit perceptions of brand extension in informational advertising. Future studies should extend the number of observations from different backgrounds and add the level of loyalty as a controlling factor as the more loyal consumers' toward the parent brand, the more positive their attitude toward the extended brand. 


\section{References}

Aaker, D. A., \& Keller, K. L. (1990). Consumer evaluations of brand extensions. Journal of Marketing, 54(1), 27-41. https://doi.org/10.1177/002224299005400102

Alavinasab, S., Soltani, M., \& Alimohammadi, J. (2017). The effect of brand extension strategy on brand image to customers. British Journal of Economics, Management \& Trade, 17(4), 1-9. https://doi.org/10.9734/BJEMT/2017/32736

Albrecht, C.-M., Backhaus, C., Gurzki, H., \& Woisetschläger, D. M. (2013). Drivers of brand extension success: What really matters for luxury brands. Psychology \& Marketing, 30(8), 647-659. https://doi.org/10.1002/mar.20635

Arikan, E., Yilmaz, C., \& Bodur, M. (2016). Expanding the boundary of brand extensions through brand relationship quality. Journal of Business Economics and Management, 17(6), 930-944. https://doi.org/10.3846/16111699.2016.1220420

Audrin, C., Brosch, T., Chanal, J., \& Sander, D. (2017). When symbolism overtakes quality: Materialists consumers disregard product quality when faced with luxury brands. $\begin{array}{llll}\text { Journal of } & \text { Economic }\end{array}$ https://doi.org/10.1016/j.joep.2017.04.001

Bairrada, C. M., Coelho, F., \& Coelho, A. (2018). Antecedents and outcomes of brand love: utilitarian and symbolic brand qualities. European Journal of Marketing, 52(3/4), 656682. https://doi.org/10.1108/EJM-02-2016-0081

Barone, M. J. (2005). The interactive effects of mood and involvement on brand extension evaluations. Journal of Consumer Psychology, 15(3), 263-270. https://doi.org/10.1207/s15327663jcp1503_11

Belch, M. A., \& Belch, G. E. (2013). The future of creativity in advertising. Journal of Promotion Management, 19(4), 395-399. https://doi.org/10.1080/10496491.2013.817219

Bhat, S., \& Reddy, S. K. (2001). The impact of parent brand attribute associations and affect on brand extension evaluation. Journal of Business Research, 53(3), 111-122. https://doi.org/10.1016/S0148-2963(99)00115-0

Boisvert, J., \& Ashill, N. J. (2018). The spillover effect of downward line extensions on U.S. consumers' evaluation of a French luxury parent brand: The role of branding strategies, authenticity, and fit. Psychology \& Marketing, 35(10), 740-751. https://doi.org/10.1002/mar.21131

Bottomley, P. A., \& Holden, S. J. S. (2001). Do we really know how consumers evaluate 
Consumer response to different advertising appeals: The role of brand value and the perceptual fit of an extended brand for high-involvement products by Rosa Prafitri Juniarti, Adi Zakaria Afiff brand extensions? Empirical generalizations based on secondary analysis of eight studies. Journal of Marketing Research, 38(4), 494-500. https://doi.org/10.1509/jmkr.38.4.494.18901

Carter, R. E., \& Curry, D. J. (2013). Perceptions versus performance when managing extensions: new evidence about the role of fit between a parent brand and an extension. Journal of the Academy of Marketing Science, 41(2), 253-269. https://doi.org/10.1007/s11747-011-0292-z

Chaabane, A. M., \& Pez, V. (2017). "Make me feel special": Are hierarchical loyalty programs a panacea for all brands? The role of brand concept. Journal of Retailing and Consumer Services, 38, 108-117. https://doi.org/10.1016/j.jretconser.2017.05.007

Childs, M., \& Jin, B. E. (2020). Retailer-brand collaborations: testing key strategies to increase consumers' urgency to buy. International Journal of Retail \& Distribution Management, 48(4), 380-394. https://doi.org/10.1108/IJRDM-06-2019-0199

Dedeoğlu, B. B. (2018). Chapter 11 The Moderating Effect of Perceived Value on the Relationship between Country Image and Destination Brand Extension in Alanya, Turkey. In The Branding of Tourist Destinations: Theoretical and Empirical Insights (pp. 185-205). Emerald Publishing Limited. https://doi.org/10.1108/978-1-78769-373920181011

Dens, N., \& De Pelsmacker, P. (2010a). Advertising for extensions: Moderating effects of extension type, advertising strategy, and product category involvement on extension evaluation. Marketing Letters, 21(2), 175-189. https://doi.org/10.1007/s11002-0099086-1

Dens, N., \& De Pelsmacker, P. (2010b). Attitudes toward the extension and parent brand in response to extension advertising. Journal of Business Research, 63(11), 1237-1244. https://doi.org/10.1016/j.jbusres.2009.11.004

Dwivedi, A., Merrilees, B., \& Sweeney, A. (2010). Brand extension feedback effects: A holistic framework. Journal of Brand Management, 17(5), 328-342. https://doi.org/10.1057/bm.2009.26

Eren-Erdogmus, I., Akgun, I., \& Arda, E. (2018). Drivers of successful luxury fashion brand extensions: cases of complement and transfer extensions. Journal of Fashion Marketing and Management: An International Journal, 22(4), 476-493. https://doi.org/10.1108/JFMM-02-2018-0020

Eren-Erdogmuş, İ., \& Büdeyri-Turan, I. (2012). The role of personality congruence, perceived quality and prestige on ready-to-wear brand loyalty. Journal of Fashion 
Marketing and Management: An International Journal, 16(4), 399-417. https://doi.org/10.1108/13612021211265818

Esmaeilpour, F. (2015). The role of functional and symbolic brand associations on brand loyalty. Journal of Fashion Marketing and Management: An International Journal, 19(4), 467-484. https://doi.org/10.1108/JFMM-02-2015-0011

Ferguson, G., Lau, K. C., \& Phau, I. (2016). Brand personality as a direct cause of brand extension success: does self-monitoring matter? Journal of Consumer Marketing, 33(5), 343-353. https://doi.org/10.1108/JCM-04-2014-0954

Figueiredo, J., \& Eiriz, V. (2020). Fragrances' luxury brand extension: consumer behaviour and influences. EuroMed Journal of Business, ahead-of-p(ahead-of-print). https://doi.org/10.1108/EMJB-04-2020-0038

Flores, W., Chen, J.-C. V., \& Ross, W. H. (2014). The effect of variations in banner ad, type of product, website context, and language of advertising on Internet users' attitudes. Computers in Human Behavior, 31, 37-47. https://doi.org/10.1016/j.chb.2013.10.006

Gierl, H., \& Huettl, V. (2010). Are scarce products always more attractive? The interaction of different types of scarcity signals with products' suitability for conspicuous consumption. International Journal of Research in Marketing, 27(3), 225-235. https://doi.org/10.1016/j.ijresmar.2010.02.002

Hadi, N. U., \& Sandhu, N. (2020). Conceptualizing perceived quality of parent brand and brand extension evaluation relationship: What is the role of style of thinking? Discourse, 6(1), 199-208.

Henseler, J., Horváth, C., Sarstedt, M., \& Zimmermann, L. (2010). A cross-cultural comparison of brand extension success factors: A meta-study. Journal of Brand Management, 18(1), 5-20. https://doi.org/10.1057/bm.2010.25

Hultman, M., Papadopoulou, C., Oghazi, P., \& Opoku, R. (2020). Branding the hotel industry: The effect of step-up versus step-down brand extensions. Journal of Business Research. https://doi.org/10.1016/j.jbusres.2020.10.047

Joshi, R., \& Yadav, R. (2018). Exploring the mediating effect of parent brand reputation on brand equity. Paradigm, 22(2), 125-142. https://doi.org/10.1177/0971890718787903

Kim, K., \& Park, J. (2019). Cultural influences on brand extension judgments: Opposing effects of thinking style and regulatory focus. International Journal of Research in Marketing, 36(1), 137-150. https://doi.org/10.1016/j.ijresmar.2018.09.006

Kim, K., Park, J., \& Kim, J. (2014). Consumer-brand relationship quality: When and how it helps brand extensions. Journal of Business Research, 67(4), 591-597. 
Consumer response to different advertising appeals: The role of brand value and the perceptual fit of an extended brand for high-involvement products by Rosa Prafitri Juniarti, Adi Zakaria Afiff https://doi.org/10.1016/j.jbusres.2013.03.001

Kim, S., Haley, E., \& Koo, G.-Y. (2009). Comparison of the paths from consumer involvement types to ad responses between corporate advertising and product advertising. Journal of Advertising, 38(3), 67-80. https://doi.org/10.2753/JOA00913367380305

Klink, R. R., \& Smith, D. C. (2001). Threats to the external validity of brand extension research. Journal of Marketing Research, 38(3), 326-335. https://doi.org/10.1509/jmkr.38.3.326.18864

Kwon, J., Seo, Y., \& Ko, D. (2016). Effective luxury-brand advertising: The es-if matching (entity-symbolic versus incremental-functional) model. Journal of Advertising, 45(4), 459-471. https://doi.org/10.1080/00913367.2016.1226995

Kwun, D. J.-W., \& Oh, H. (2007). Consumers' evaluation of brand portfolios. International Journal of Hospitality Management, 26(1), 81-97. https://doi.org/10.1016/j.ijhm.2005.09.003

Lau, K. C., \& Phau, I. (2007). Extending symbolic brands using their personality: Examining antecedents and implications towards brand image fit and brand dilution. Psychology and Marketing, 24(5), 421-444. https://doi.org/10.1002/mar.20167

Liu, X., Hu, J., \& Xu, B. (2017). Does eWOM matter to brand extension? Journal of Research in Interactive Marketing, 11(3), 232-245. https://doi.org/10.1108/JRIM-022016-0012

Lye, A., Venkateswarlu, P., \& Barrett, J. (2001). Brand extensions: Prestige brand effects. Australasian Marketing Journal (AMJ), 9(2), 53-65. https://doi.org/10.1016/S14413582(01)70175-9

Matthes, J. (2013). The affective underpinnings of hostile media perceptions. Communication Research, 40(3), 360-387. https://doi.org/10.1177/0093650211420255

Milberg, S. J., \& Sinn, F. (2008). Vulnerability of global brands to negative feedback effects. Journal of Business Research, 61(6), 684-690. https://doi.org/10.1016/j.jbusres.2007.06.045

Monga, A. B., \& John, D. R. (2010). What makes brands elastic? The influence of brand concept and styles of thinking on brand extension evaluation. Journal of Marketing, 74(3), 80-92. https://doi.org/10.1509/jmkg.74.3.080

Nan, X. (2006). Perceptual predictors of global attitude toward advertising: An investigation of both generalized and personalized beliefs. Journal of Current Issues \& Research in Advertising, 28(1), 31-44. https://doi.org/10.1080/10641734.2006.10505189 
O’Reilly, K. A., Mumuni, A. G., Newell, S. J., \& Addicott, B. J. (2017). Parent brand quality, service intensity and consumers' usage consideration of service-to-service brand extensions. Journal of Product \& Brand Management, 26(7), 690-703. https://doi.org/10.1108/JPBM-08-2016-1299

Pashna, M., Esfidani, M. R., \& Jafari, S. M. bagher. (2019). The role of user involvement, user involvement types, product category involvement and advertising appeals in social media advertising effectiveness: A Middle East context (Iran). Journal of Creative Communications, 14(2), 85-117. https://doi.org/10.1177/0973258619851987

Prajogo, W., \& Purwanto, E. (2020, March 17). The influence of advertising appeals on viral advertising, brand awareness, and purchase intention: The moderator role of hedonic personality. https://doi.org/10.31106/jema.v17i1.5298

Primanto, A. B., \& Dharmmesta, B. S. (2019). What happens after they laugh: How humorous advertisements have an effect on consumers' attitudes, word of mouth intentions, and purchase intentions, with the need for humor playing a moderating role. Journal of Indonesian Economy and Business, 34(2), 117. https://doi.org/10.22146/jieb.23036

Rajagopal, A. (2020). Analysing brand awareness as a driver for determining brand value: a study in telecommunications service marketing. International Journal of Services and Operations Management, 37(2), 241. https://doi.org/10.1504/IJSOM.2020.110341

Rhee, E. S., \& Jung, W. S. (2019). Brand familiarity as a moderating factor in the ad and brand attitude relationship and advertising appeals. Journal of Marketing Communications, 25(6), 571-585. https://doi.org/10.1080/13527266.2018.1461124

Salehzadeh, R., Khazaei Pool, J., \& Jafari Najafabadi, A. H. (2018). Exploring the relationship between corporate social responsibility, brand image and brand equity in Iranian banking industry. Journal of Islamic Accounting and Business Research, 9(2), 106-118. https://doi.org/10.1108/JIABR-11-2014-0041

Sharma, A., \& Paudel, P. K. (2018). Determinants of green brand trust and the mediating role of green brand satisfaction. International Research Journal of Management Science, 3, 1-24. https://doi.org/10.3126/irjms.v3i0.28033

Shokri, M., \& Alavi, A. (2019). The relationship between consumer-brand identification and brand extension. Journal of Relationship Marketing, 18(2), 124-145. https://doi.org/10.1080/15332667.2018.1534064

Teichert, T., Hardeck, D., Liu, Y., \& Trivedi, R. (2018). How to implement informational and emotional appeals in print advertisements. Journal of Advertising Research, 58(3), 363- 
Consumer response to different advertising appeals: The role of brand value and the perceptual fit of an extended brand for high-involvement products by Rosa Prafitri Juniarti, Adi Zakaria Afiff 379. https://doi.org/10.2501/JAR-2017-054

Verhellen, Y., Dens, N., \& De Pelsmacker, P. (2016). Do I know you? How brand familiarity and perceived fit affect consumers' attitudes towards brands placed in movies. Marketing Letters, 27(3), 461-471. https://doi.org/10.1007/s11002-015-9347-0

Völckner, F., \& Sattler, H. (2006). Drivers of brand extension success. Journal of Marketing, 70(2), 18-34. https://doi.org/10.1509/jmkg.70.2.018

Yang, D. (2012). The strategic management of store brand perceived quality. Physics Procedia, 24, 1114-1119. https://doi.org/10.1016/j.phpro.2012.02.166

Yuan, R., Liu, M. J., Luo, J., \& Yen, D. A. (2016). Reciprocal transfer of brand identity and image associations arising from higher education brand extensions. Journal of Business Research, 69(8), 3069-3076. https://doi.org/10.1016/j.jbusres.2016.01.022

Zhang, H., Xu, H., \& Gursoy, D. (2020). The effect of celebrity endorsement on destination brand love: A comparison of previous visitors and potential tourists. Journal of $\begin{array}{llllll}\text { Destination } \quad \text { Marketing } \quad \& \quad \text { Management, } & 17, & 100454 .\end{array}$ https://doi.org/10.1016/j.jdmm.2020.100454

Zhu, X., Teng, L., Foti, L., \& Yuan, Y. (2019). Using self-congruence theory to explain the interaction effects of brand type and celebrity type on consumer attitude formation. Journal of Business Research, 103, 301-309. https://doi.org/10.1016/j.jbusres.2019.01.055 


\section{Appendix 1a. Printed Ad Stimulus Symbolic - Low Fit - Emotional}

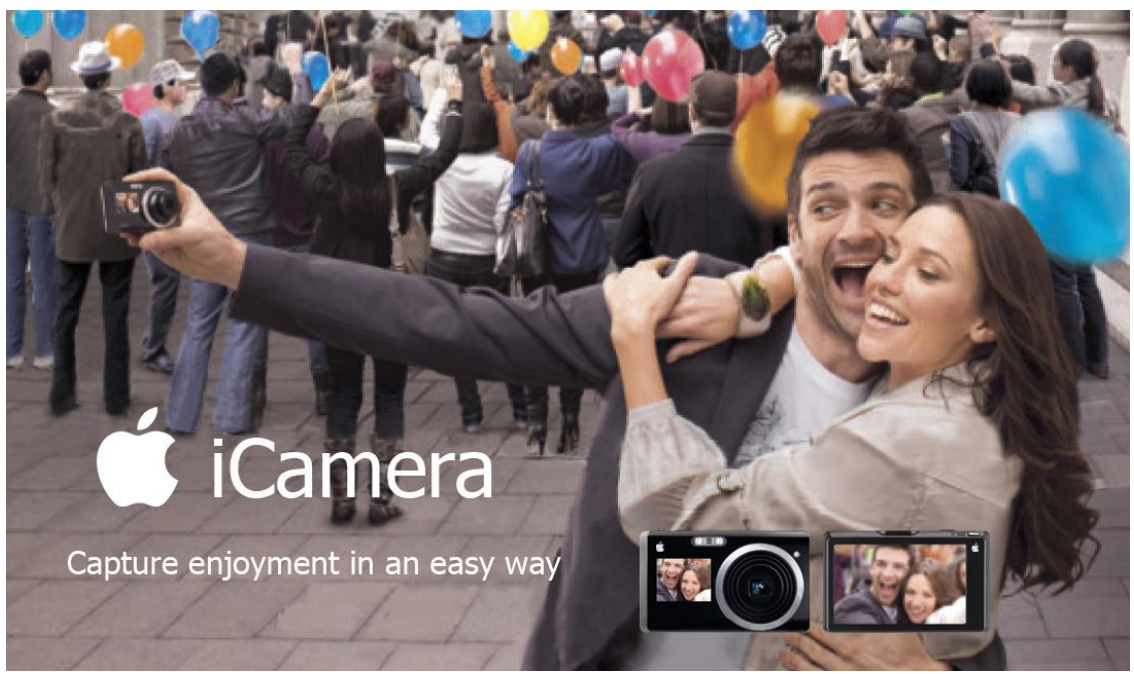

Appendix 1b. Printed Ad Stimulus Functional - Low Fit - Emotional



Appendix 1c. Printed Ad Stimulus Symbolic - Low Fit - Informational

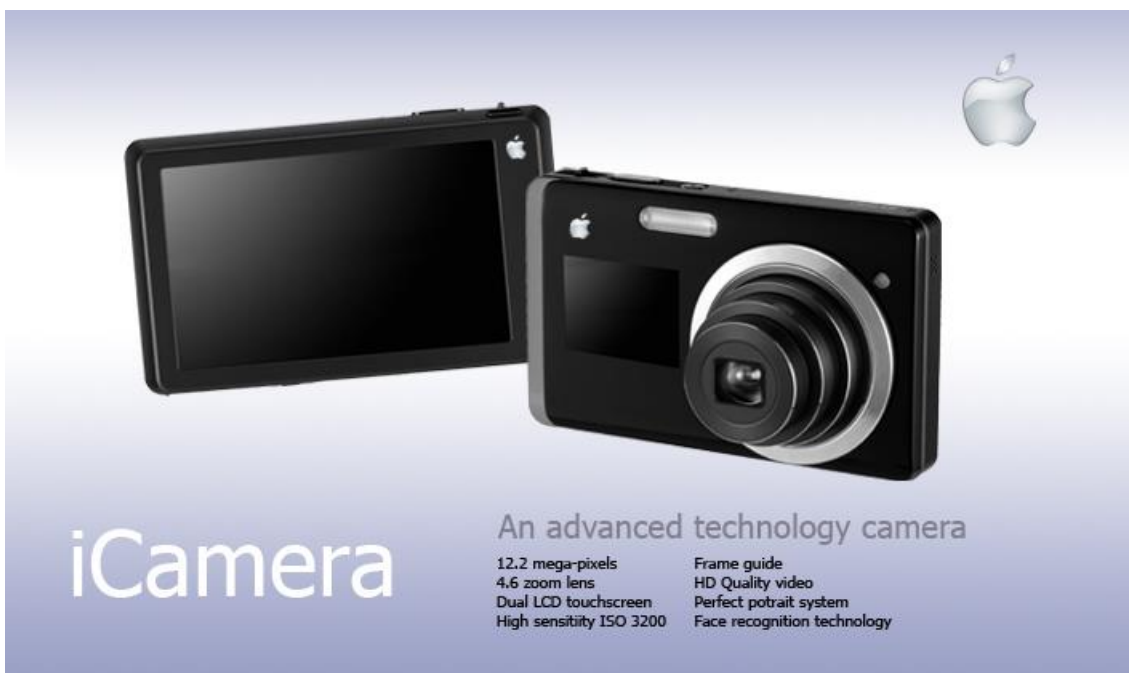


Consumer response to different advertising appeals: The role of brand value and the perceptual fit of an extended brand for high-involvement products by Rosa Prafitri Juniarti, Adi Zakaria Afiff

Appendix 1d. Printed Ad Stimulus Functional - Low Fit - Informational

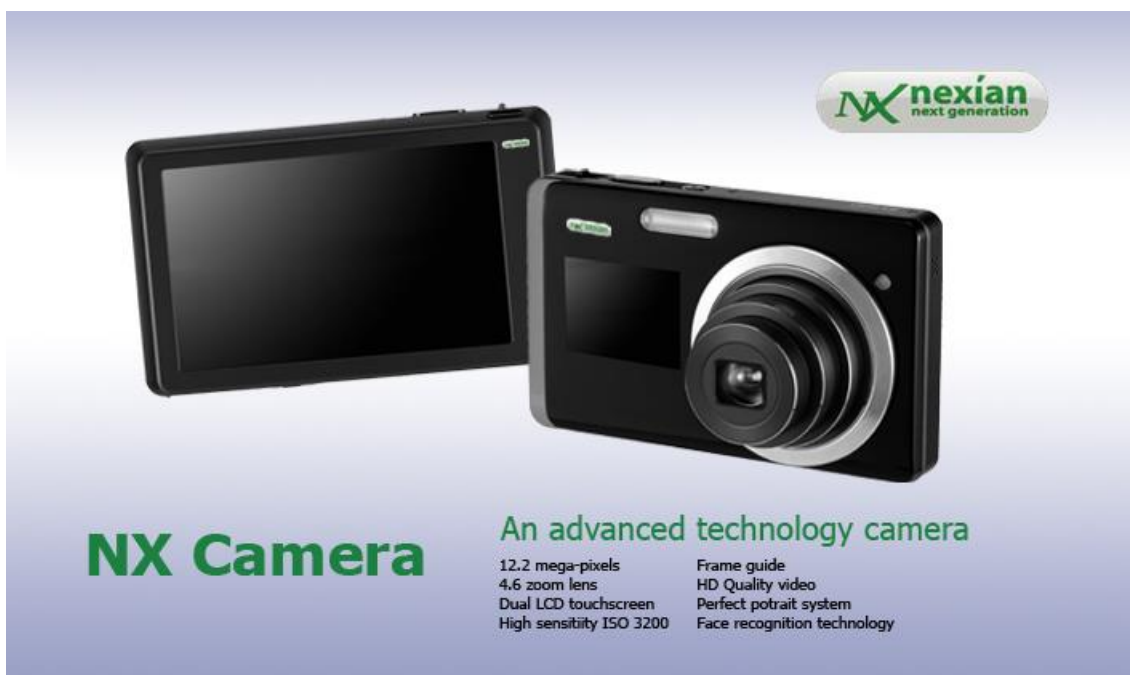

Appendix 1e. Printed Ad Stimulus Symbolic - High Fit - Emotional

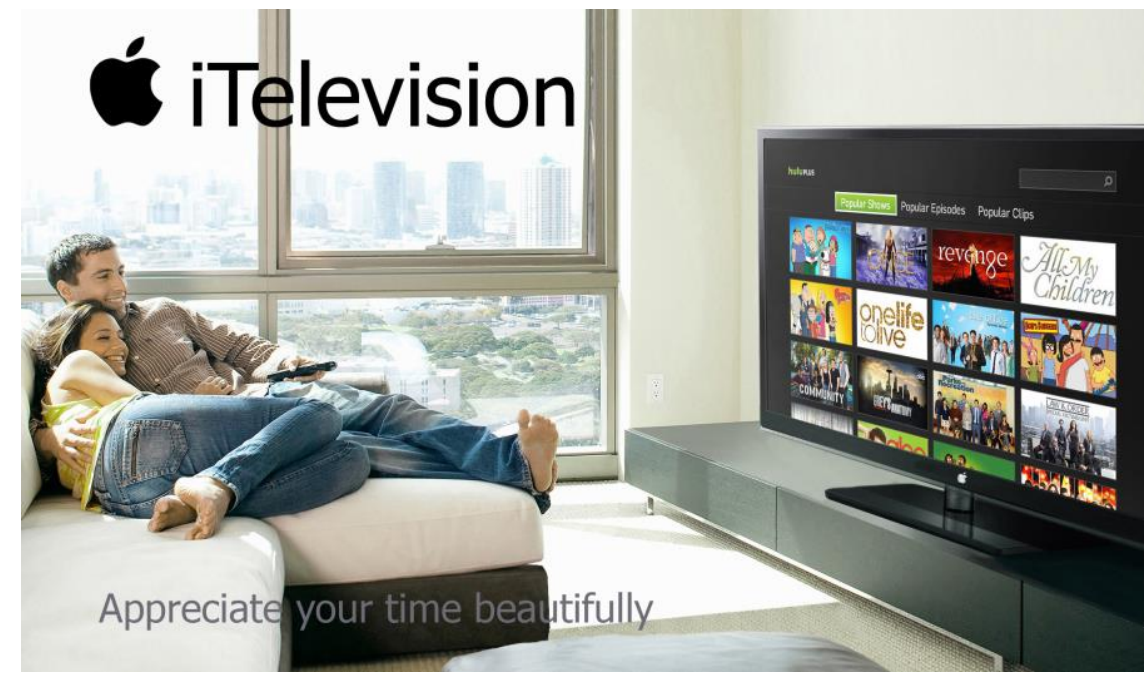

Appendix 1f. Printed Ad Stimulus Functional - High Fit - Emotional




Appendix 1g. Printed Ad Stimulus Symbolic - High Fit - Informational

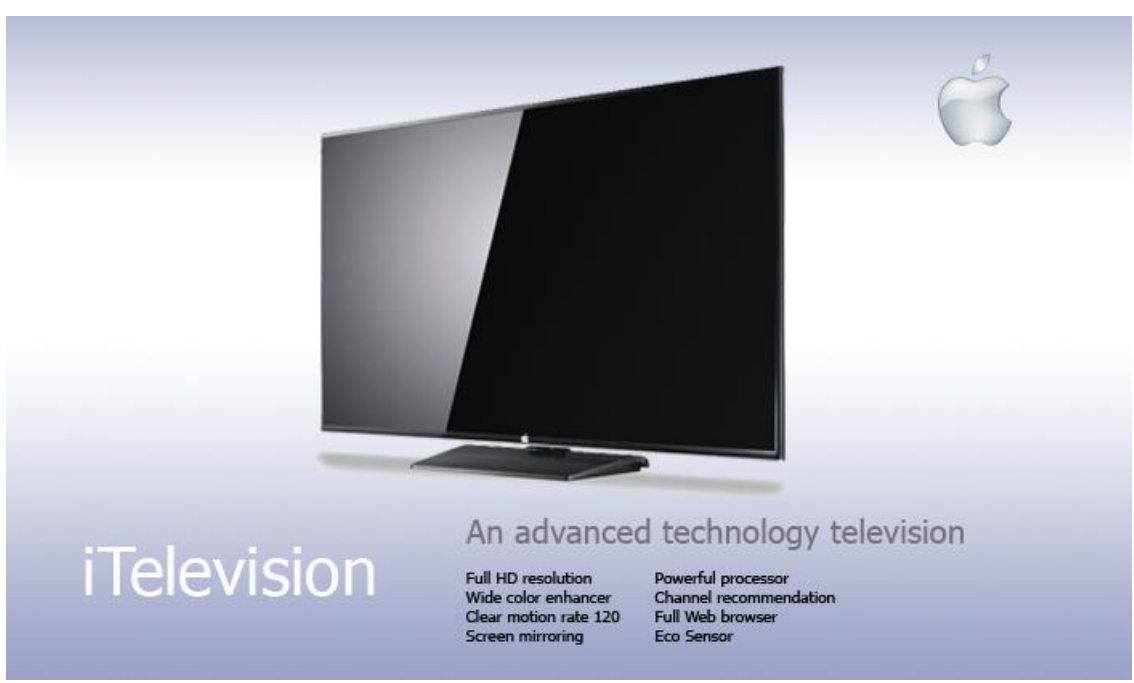

Appendix 1h. Printed Ad Stimulus Functional - High Fit - Informational

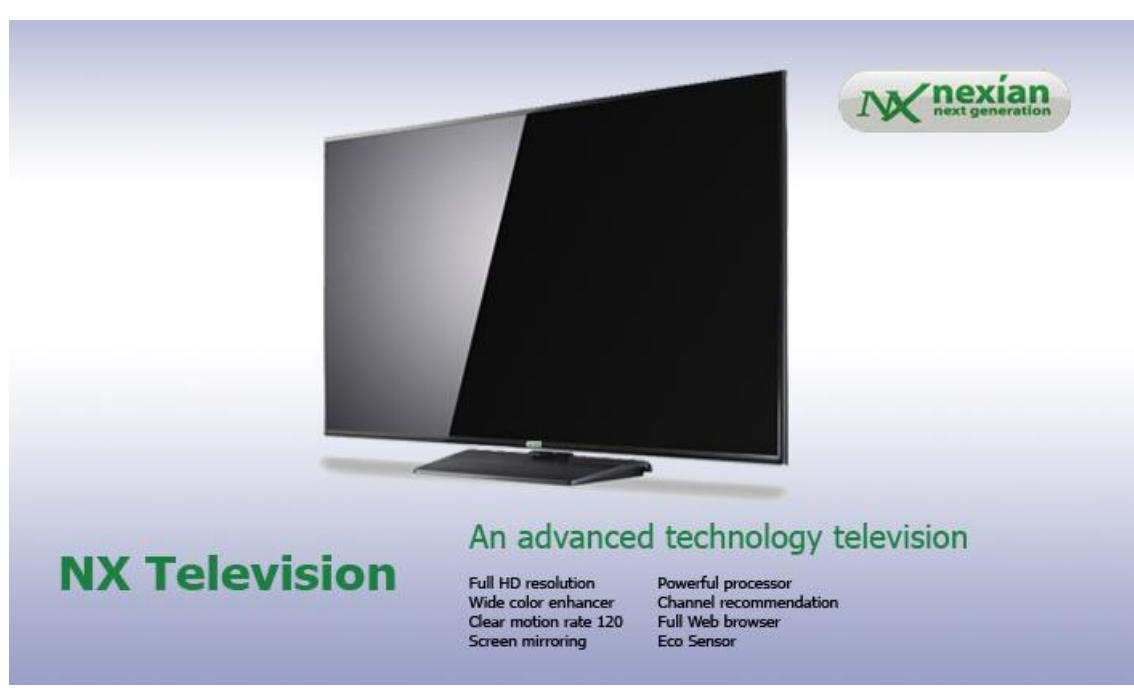

